DAKWATUNA

Jurnal Dakwah dan Komunikasi Islam

Volume 6, Nomor 2, Agustus 2020

p-ISSN: 2443-0617

e-ISSN: 2686-1100

\title{
Pemanfaatan Media Sosial Komunitas Untuk Menghadapi Konten Islam Ekstrim Di Internet
}

\author{
Arini Indah Nihayaty \\ Universitas Airlangga, Indonesia \\ Email: arini.indah.nihayaty-2018@fisip.unair.ac.id \\ Atikah Mardhiya Rohmy \\ Universitas Merdeka Malang \\ Email: atikahrochmy@gmail.com
}

\begin{abstract}
Terrorism and radicalism, in the name of religion, which in nature deconstruct the development of the existing state, must be completely eliminated. Moreover, if terrorism and radicalism, by making social media a means of recruiting members. If so, the policy makers must intervene and make a stronghold in the digital space. In addition, there must be a step from the community exponents to participate in combating terrorism and radicalism. For example, from Islamic boarding schools and Islamic community organizations, such as Nahdlatul Ulama or NU and Muhammadiyah, in Indonesia. The existence of NU and Muhammadiyah is central because so far, they have played a role in advancing the nation from all fronts. The activeness of these two community organizations in counter movement, dealing with terrorism and radicalism is a must. Ways that can be taken include da'wah or the spread of positive messages through social media. What is aggressively done through time and space.

Keywords: Da'wah, Social Media, Terrorism, Radicalism
\end{abstract}

\begin{abstract}
Abstrak
Terorisme dan radikalisme dalam beragama, yang sifatnya mendekonstruksi pembangunan negara yang telah ada, tentu mesti dikikis habis. Terlebih, bila terorisme dan radikalisme itu mengekor perkembangan zaman, dengan cara menjadikan media sosial sebagai sarana perekreutan anggota. Bila sudah demikian, para pemangku kebijakan harus turun tangan dan membuat benteng pertahanan di dunia digital. Selain itu, mesti ada langkah dari eksponen masyarakat untuk turut serta memerangi terorisme maupun radikalisme. Misalnya, dari kalangan pesantren dan orgaisasi masyarakat Islam, seperti Nahdlatul Ulama atau NU dan Muhammadiyah. Keberadaan NU dan Muhammadiyah menjadi sentral karena selama ini, mereka sudah ikut berperan memajukan bangsa dari segala lini. Keaktifan dua organisasi masyarakat ini dalam menghadapi terorisme dan radikalisme merupakan
\end{abstract}


sebuah keharusan. Cara yang bisa ditempuh antara lain, dakwah atau penyebaran pesan-pesan positif melalui media sosial. Yang gencar dilakukan menembus ruang dan waktu.

Kata Kunci : Dakwah, Media Sosial, Terorisme, Radikalisme

\section{PENDAHULUAN}

Dalam The Concise Oxford Dictionary (1987) radikal berasal dari bahasa latin "radix, radicis" yang berarti akar, sumber atau asal mula. Radikalisme berasal dari akar kata radikal. Dalam kamus besar bahasa Indonesia "radikalisme" didefinisikan sebagai paham atau aliran yang menginginkan perubahan atau pembaharuan sosial dan politik dengan cara kekerasan atau drastis. Menurut Dr. Alex P. Schmid, radikalisme jauh lebih tidak bermasalah bagi masyarakat demokratis daripada ekstremisme. Radikal bias bersifat reformis dan tanpa kekerasan. Radikalis sejati cenderung lebih pragmatis dan terbuka terhadap penalaran kritis. ("Radicalisation, De-Radicalisation, CounterRadicalisation: A Conceptual Discussion and Literature Review", 2014:56).

Sementara menurut Prof. Dr. Irfan Idris, Direktur Deradikalisasi Badan Nasional Penanggulangan Terorisme (BNPT), ada proses tersendiri seseorang mengalami perubahan dari seseorang yang radikalis, ekstrimis, hingga menjadi teroris. Radikalisme mengalami perubahan secara total dan bersifat drastis. Radikalisme menjungkirbalikkan nilai-nilai yang ada, ciri-cirinya adalah mereka intoleran atau tidak memiliki toleransi pada golongan yang memiliki pemahaman berbeda di luar golongan mereka, mereka juga cenderung fanatik, eksklusif dan tidak segan menggunakan cara-cara anarkis.

Menurut Merriam-Webster Dictionary, ekstremisme secara harfiah artinya "kualitas atau keadaan yang menjadi ekstrem" atau "advokasi ukuran atau pandangan ekstrim". Saat ini, istilah tersebut banyak dipakai dalam esensi politik atau agama, yang merujuk kepada ideologi yang dianggap (oleh yang menggunakan istilah ini atau beberapa orang yang mematuhi konsensus sosial) berada jauh di luar sikap masyarakat pada umumnya. Namun, ekstremisme juga dipakai dalam diskursus ekonomi. 
Menurut Dr. Alex P. Schmid (2014), kelompok ekstrimis merupakan kelompok yang menganut paham kekerasan ekstrim atau ekstrimisme. dibandingkan radikalis, ekstrimis cenderung berpikiran tertutup, tidak bertoleransi, anti-demokrasi dan bisa menghalalkan segala cara, termasuk penipuan, untuk mencapai tujuan mereka. Kelompok ekstrimis juga berpikiran tertutup. Kelompok ini berbeda dengan kelompok radikalis, kelompok yang menganut paham radikal atau radikalisme. ("Radicalisation, De-Radicalisation, Counter-Radicalisation: A Conceptual Discussion and Literature Review”, 2014: h. 56)

Menurut Dr. Alex P. Schmid (2013), radikalisasi adalah proses dimana Individu atau kelompok yang berubah dan memiliki kecenderungan menentang dialog dan kompromi dengan pihak yang berbeda; mereka memilih jalan konfrontasi dan konflik. Pilihan ini disertai oleh dukungan terhadap (i) penggunaan tekanan dan strategi memaksa (coersion) dengan jalan kekerasan atau non-kekerasan, (ii) legitimasi atau dukungan terhadap berbagai bentuk kekerasan, selain terorisme, untuk mewujudkan tujuanya yang dianggap mulia, dan (iii) pada ujungnya bisa berlanjut ke level tertinggi dalam bentuk kekerasasan ekstrim atau terorisme. Proses ini biasanya diikuti oleh kecenderungan penguatan ideologi yang menjauh dari arus utama (mainstream) dan mengarah kepada titik ekstrim yang didasari oleh cara pandang dikotomis dan keyakinan bahwa kemapanan sistem yang ada tidak lagi bisa menjadi jalan bagi terjadinya perubahan yang diinginkan. Proses perubahan seseorang dari radikalis menuju ekstrimis hingga melakukan aksi teror tidak terlepas dari proses radikalisasi, sehingga mereka yang sudah teradikalisasi tidak segan menggunakan cara-cara kekerasan ekstrim untuk mewujudkan perjuangannya, termasuk aksi teror.

Menurut Direktur Deradikalisasi BNPT, Prof. Dr. Irfan Idris, tahapan radikalisasi adalah pra-radikalisasi, identifikasi diri, indoktrinasi, dan jihadisasi. Pra-radikalisasi merupakan kehidupan sebelum terjadi radikalisasi. Identifikasi 
diri adalah individu mulai mengidentifikasi diri ke arah radikalisme. Indoktrinasi adalah kondisi dimana individu mulai mengintensifkan dan memfokuskan kepercayaannya, hal ini bisa dilakukan melalui pertemuan langsung (offline), maupun tidak langsung atau melalui media (online). Tahap terakhir adalah Jihadisasi, yaitu mulai mengambil tindakan atas keyakinannya seperti melalui aksi kekerasan ekstrim seperti melakukan teror.

Menurut UU Nomor 15 Tahun 2003, terorisme adalah penggunaan kekerasan atau ancaman kekerasan yang menimbulkan situasi teror atau rasa takut terhadap orang secara meluas dan menimbulkan korban yang bersifat massal, dengan cara merampas harta benda orang lain, yang mengakibatkan kerusakan atau kehancuran obyek-obyek vital strategis, lingkungan hidup, fasilitas publik dan fasilitas internasional. Seseorang atau kelompok radikalis dapat mengalami perubahan menggunakan cara-cara ekstrim, termasuk kekerasan ekstrim melalui aksi teror dipengaruhi banyak hal. Mulai dari pengaruh faktor yang bersifat internasional seperti ketidakadilan global, politik luar negeri yang arogan, dan penjajahan. Selain itu juga dipengaruhi faktor domestik seperti persepsi ketidakadilan, kesejahteraan, pendidikan, kecewa pada pemerintah, serta balas dendam. Di luar faktor internasional dan domestik, faktor lainnya adalah faktor kultural, yaitu karena pemahaman agama yang dangkal, penafsiran agama yang sempit dan tekstual, dan indoktrinasi ajaran agama yang salah. Menurut Direktur Deradikalisasi BNPT, Prof. Dr. Irfan Idris, PMI terjebak kelompok ekstrimis melalui kontak di media sosial dan berlanjut di pertemuan offline. Penyebaran paham ekstrimis dan perekrutan teroris, belakangan, dilakukan melalui website, media sosial dan messanger. Hal semacam ini mesti disikapi dengan tepat oleh para pemangku kebijakan atau elemen yang memangku kepentingan.

\footnotetext{
${ }^{1}$ Ahmad Zamzamy. (2019). Menyoal Radikalisme di Media Digital. Dakwatuna: Jurnal Dakwah dan Komunikasi Islam, 5(1), 13-29.
} 
Kehadiran internet menjadi penanda lahirnya era new media. Di mana arus informasi menjadi sangat deras. Sumbernya bisa dari mana saja dan dapat dilontarkan ke arah manapun. Implikasi kongkret dari kemunculan internet adalah terciptanya banyak jejaring/media sosial. Jejaring/media sosial seperti Facebook, Twitter, Instagram, adalah sebagian contoh yang hingga kini masih bertahan dan memiliki banyak pengguna baik di Indonesia maupun di dunia.

Pergeseran cara berkomunikasi masyarakat menjadi begitu pesat. Interaksi manusia melalui internet sangat dinamis dan tanpa henti selama 24 jam. Jika pada awal kelahirannya, internet hanya menjadi media mencari informasi dari satu website ke website lain, kini dengan perangkat media sosial, cara hidup dan kebudayaan manusia mengalami revolusi besar-besaran. Tak ayal, pemerintah berlomba-lomba untuk menguatkan teknologi komunikasi dan informasi untuk mencapai kesejahteraan masyarakat dan keseteraan sosial ${ }^{2}$. Bahkan, banyak pula program maupun kebijakan ekonomi maupun industri kreatif yang bertolak dari perkembangan media digital ${ }^{3}$.

Berdasarkan data dari www.internetsehat.id yang dilansir pada 2016, dari jumlah populasi penduduk Indonesia sekitar 259,1 juta, 88,1 juta adalah pengguna internet aktif. Sedangkan 79 juta merupakan pengguna media sosial aktif. Terdapat 326 juta telepon seluler yang aktif di Indonesia, dengan 66 juta di antaranya dipakai untuk mengakses media sosial. Rata-rata, seseorang mengakses internet per hari melalui PC/komputer selama 4 jam 42 menit, melalui telepon seluler selama 3 jam 33 menit. Masih menurut riset yang sama, diketahui kalau seseorang mengakses media sosial per hari melalui telepon seluler selama 2 jam 51 menit.

\footnotetext{
${ }^{2}$ Rio Febriannur Rachman. (2019). Optimalisasi Teknologi Komunikasi Informasi Command Center Bagi Efektifitas Tenaga Kesejahteraan Sosial Kecamatan. Dakwatuna: Jurnal Dakwah dan Komunikasi Islam, 5(2), 170-180.

3 Rio Febriannur Rachman. (2019). Optimalisasi Media Digital Berbasis Kemaslahatan Umat dalam Program Pahlawan Ekonomi Surabaya. IQTISHODUNA: Jurnal Ekonomi Islam, 8, 273-292.
} 
Rentang usia para netizen atau warga internet (warganet) bervariasi. Mulai mereka yang berumur muda (18-25 tahun) dan digolongkan sebagai digital natives, hingga mereka yang berusia lanjut pada kisaran 65 tahun. Memang, digital natives tercatat sebagai pengguna dengan jumlah terbanyak (49 persen). Disusul mereka yang berusia di rentang 26-35 tahun (33,8 persen), 36-45 tahun (14,6 persen), 46-55 tahun (2,4 persen), dan 56-65 tahun (0,2 persen).

Televisi sebagai media massa paling populer di era 90-an, sudah tergeser posisinya. Berdasarkan riset dari www.internetsehat.id, masyarakat mengakses internet jauh lebih lama daripada menyaksikan televisi. Per hari, seseorang mengakses internet melalui PC/komputer selama 4 jam 42 menit, dan mengakses internet melalui telepon seluler selama 3 jam 33 menit, sedangkan untuk menyaksikan televisi, rata-rata per orang dalam sehari "hanya" 2 jam 22 menit.

Jumlah masyarakat yang mengakses media sosial semakin hari semakin besar. Seiring dengan makin mudah dan luasnya capaian jaringan internet ke pelosok. Makin banyaknya area hotspot wifi di sentra publik juga berpengaruh signifikan terhadap meningkatnya jumlah pengguna media sosial ${ }^{4}$. Keadaan masyarakat dalam kemajuan teknologi informasi seperti saat ini dapat ditelaah dengan sebuah teori komunikasi klasik. Yakni, teori two-step flow of communication model yang dipopulerkan sosiolog asal Amerika Serikat Paul Felix Lazarsfeld pada 1944 yang kemudian dikembangkan oleh Elihu Katz pada kisaran 1955. Teori ini menyebutkan, perspektif masyarakat dipengaruhi oleh opinion leader dari pusat informasi, yang dalam penelitian berperspektif dakwah ini, dapat dikategorikan pula pada sumber pengetahuan keagamaan. Sumber yang dimaksud, dapat merujuk pada lembaga pesantren. Jadi, untuk

\footnotetext{
${ }^{4}$ Rio Febriannur Rachman. (2017). Menelaah riuh budaya masyarakat di dunia maya. Jurnal Studi Komunikasi, 1(2), 206-222.
} 
dapat masuk dan memengaruhi pusaran informasi, pesantren mesti menjalankan model komunikasi dan sinergitas yang interaktif.

Sudah banyak riset yang menunjukkan bahwa dakwah bisa menjadi efektif, interaktif, dan efisien, melalui jalur media sosial yang bersemangat kultural atau berbasis kearifan lokal5. Yang jelas, dakwah maupun pesan-pesan kebaikan dari eksponen masyarakat Islam mesti disesuaikan dengan perkembangan zaman6. Dakwah di era kekinian mesti mengedepankan keramahan, sehingga tidak ada kesan radikal dalam beragama7. Bagaimana pun juga, di era milenial seperti sekarang ini, dakwah mesti dikemas sebaik mungkin sehingga dapat mencapai tujuannya: menyebarkan kebaikan dan agama Islam ${ }^{8}$.

Dalam buku Communication Works karya Michael Gamble dan Teri Kwal Gamble9, ada empat ciri fenomena media sosial. Pertama, pesan yang disampaikan tidak hanya untuk satu orang, tapi untuk banyak orang atau bisa diakses oleh banyak orang. Kedua, pesan yang disampaikan bebas tanpa melalui sistem sortir, baik berupa editing maupun gatekeeper. Ketiga, pesan yang disampaikan cenderung lebih cepat dibanding media lainnya. Keempat, penerima pesan yang menentukan waktu interaksi. Dari semua hal tadi, bisa dipahami bahwa kebebasan yang ada di media sosial begitu luas dan dapat menjadi celah peluang bagi penyebar konten-konten ekstrim Islam, radikalis, dan teroris, baik untuk merekrut pengikut maupun memantik empati masyarakat luas pada paham yang sesat tersebut.

Maka itu, penting bagi komunitas-komunitas Islam untuk menyiapkan konten "tandingan" atau konten antisipatif guna menghadapi penyebaran

\footnotetext{
${ }^{5}$ Rio Febriannur Rachman. (2018). Dakwah Intraktif Kultural Emha Ainun Nadjib. Jurnal Spektrum Komunikasi, 6(2), 1-9.

${ }^{6}$ M. Darwis. (2016). Teologi Dakwah Dalam Kajian Paradigmatik. Dakwatuna: Jurnal Dakwah dan Komunikasi Islam, 2(1), 85-106.

7 Faiqotul Mala. (2020). Mengkaji Tradisi Nabi Sebagai Paradigma Dakwah Yang Ramah. Dakwatuna: Jurnal Dakwah dan Komunikasi Islam, 6(01), 104-127.

${ }^{8}$ Abdul Ghofur. (2019). Dakwah Islam Di Era Milenial. Dakwatuna: Jurnal Dakwah dan Komunikasi Islam, 5(2), 136-149.

9 Gamble, M. \& Teri K. G. Communication Works. Boston: McGraw Hill Education, 2002
} 
informasi sesat tersebut di internet. Dua komunitas besar di Indonesia, seperti Nahdlatul Ulama (NU) dan Muhammadiyah, mesti ikut mengambil peran. Keduanya tentu sudah melakukan hal-hal tadi, artikel ini untuk melihat bagaimana mekanisme penyedian konten tersebut dan bagaimana upaya mengoptimalkannya. Tiap komunitas yang memiliki massa, memiliki basis-basis agen informasi, yang di era jejaring internet dapat masuk dalam label agen dakwah oleh karena kemampuan "sharing” yang dimilikinya, berikut penguatan interaksi di dalamnya, merupakan suatu keniscayaan. Yang tak kalah menarik, agen-agen informasi ini bisa pula berperan sebagai "buzzer" dalam arti positif, untuk menyalurkan informasi ke pihak-pihak yang lebih luas.

\section{PEMBAHASAN}

Dalam artikel ini, ada sejumlah riset yang dijadikan referensi. Antara lain, penelitian yang berjudul Optimalisasi Media Sosial Pesantren untuk Membendung Konten Negatif di Dunia Maya yang ditulis oleh Ahmad Farid pada 2019 dan dipublikasikan di Jurnal Dakwatuna. Dalam tulisan tersebut, Achmad Farid menyampaikan potensi media sosial yang dimiliki pondok pesantren secara umum. Artikel tersebut juga menjelaskan sejumlah konsep dan teknik optimalisasi secara praktis, mengingat pesantren selalu memiliki jaringan sosial yang kuat di internet ${ }^{10}$. Riset yang dilakukan Farid berlaku secara umum dan konseptual untuk komunitas pesantren dalam menghadapi konten negatif di dunia maya, sedangkan penelitian yang dilakukan ini bakal menunjukkan detail pemanfaatan media sosial di NU dan Muhammadiyah dalam menghadapi konten Islam ekstrim, radikal, serta bermuatan terorisme.

Penelitian lain yang dijadikan sandaran pustaka adalah Optimalisasi Penerapan e-Government melalui Media Sosial dalam Mewujudkan Good Governance yang dituliskan Wulan Sucika pada 2016. Dalam riset yang

\footnotetext{
${ }^{10}$ Farid, A. (2019). Optimalisasi Media Sosial Pesantren untuk Membendung Konten Negatif di Dunia Maya. Dakwatuna: Jurnal Dakwah dan Komunikasi Islam, 5(1), 30-37.
} 
diterbitkan di Prosiding Seminar Nasional Komunikasi itu, terdapat penjelasan tentang pentingnya peran media sosial dalam pelaksanaan e-Government. Alasannya, salah satu karakteristik media sosial adalah kemampuan untuk membawa perubahan sosial. Sedangkan e-Government adalah program yang menyentuh masyarakat dan pelaksanaannya menuntut pergeseran aktifitas dan pola pikir yang sebelumnya tidak berbasis internet, menjadi berbasis internet. Riset yang dilakukan Suciska memiliki kesamaan dengan artikel kali ini di aspek topik besar dan imlementasi sebagian teori. Yang berbeda adalah materi yang menjadi bahan kajian adalah dua komunitas Islam, NU dan Muhammadiyah, untuk mewujudkan dunia maya yang sehat dan bebas dari konten Islam ekstrim. Sebab, dakwah melalui dunia digital atau populer dengan sebutan e-dakwah, merupakan sebuah keniscayaan di era kekinian ${ }^{11}$.

Riset yang dilakukan Farid maupun Suciska, menjelaskan betapa pentingnya peran media sosial sebagai penopang strategi komunikasi di era keterbukaan informasi berbasis internet saat ini. Berkaca pada fakta itu, langkah untuk memakai media sosial bagi pihak-pihak yang ingin menyebarkan maupun menyerap informasi, sekaligus berinteraksi dengan pihak lain, sudah tidak dapat terelakkan. Dalam penelitian ini, penyebaran informasi dan interaksi mengerucut pada upaya dakwah dari dua komunitas Islam besar, NU dan Muhammadiyah, agar keduanya memiliki citra kuat sebagai pembawa pesanpesan rahmat bagi sekalian alam.

Paham Radikalisme berasal dari kata radikal yang berarti “semua sekali” atau sampai akar akarnya. Dalam Kamus Besar Bahasa Indonesia, radikalisme adalah paham atau aliran yang menghendaki perubahan social dan politik dengan cara menggunakan kekerasan sebagai batu loncatan untuk menjustifikasi keyakinan mereka yang dianggap benar. Oleh karena itu radikalisme bias dipahami sebagai paham politik kenegaraan yang

\footnotetext{
${ }^{11}$ Faiqotul Mala. (2017). “E-Dakwah”: Tinjauan Awal Kontestasi Islam, Dakwah, Dan Internet. Dakwatuna: Jurnal Dakwah dan Komunikasi Islam, 3(1), 12-26.
} 
menghendaki adanya perubahan dan revolusi besar-besaran sebagai jalan untuk mencapai taraf kemampuan yang yang signifikan. ${ }^{12}$

Kaum radikal Islam dengan bebrbagai variannya, di dalam memperjuangkan syariat Islam, penegakan khilafah Islamiyah, dan berbagai agenda lainnya bermuara pada satu titik, yaitu kembali kepada al-Qur'an dan asSunnah. Al-Qur'an dan as-Sunnah adalah satu-satunya solusi untuk memecahkan problematika umat.

Islam adalah jalan lurus (sirat al-mustaqim) yang telah di gariskanAllah di dalam al-Qur'an dan as-Sunnah yang berisi seperangkat hukum positif sebagai jalan yang benar dalam berkeyakinan, beribabadah, dan bertindak dalam kehidupan social. Sat-satunya jalan hidup manusia di muka bumi adalah merealisasikan ajaran Allah dengan melaksanakan hukum Tuhan secara utuh dan taat. Menurut kaum radikal, orang Islam yang mengikuti jalan hidup selain yang bersumber dari al-Quran dan as-Sunnah adalah kafir, munafik, dan fasik. Hal ini karena hanya ajaran yang terkandung di dalam al-Qur'an dan asSunnahlah yang dapat menciptakan tata social yang mencerminkan kebenaran Ilahi. ${ }^{13}$

Akibat dari pola piker tersebut, mereka menyuguhkan panorama keberagaman absolutism, kaku, puritan, dan intoleren terhadap berbagai perbedaan pendapat keagamaan, pemahaman terhadap teks al-Qur'an dan hadits secara literal, serta mengibarkan panji-panji kebencian, permusuhan dan kekerasan, bukan hanya kalangan nonmuslim, tetapi juga kepada internal muslim yang tidak sepaham. Segala hal yang diamalkan oleh kaum radikal akan dijustifikasi, legimitasi dan didaulat sebagai hukum Tuhan yang bersfat mutlak, absolut dan tidak bias ditawar lagi. ${ }^{14}$

12 Dirjen Bimas Islam Kementrian Agama RI. 2014. Radikalisme Agama dan Tantangan Kebangsaan. Jakarta: Dirjen Bimas Islam Kemenag RI hal

${ }^{13}$ Khalid Abou el-Fadl,2002. Cita dan Fakta Toleransi Islam .Bandung:Mizan. hal 2

14 Zaprulkhan,2014. Merenda Wajah Islam Humania, Idea Sejahtera, Yogyakarta. hal 90 
Menurut Durkheim, agama diorientasikan pada sesuatu yang dirumuskan oleh manusia sebagai sesuatu yang suci atau sakti, yaitu objek referensi yang dihargai dan bahkan dahysat. Ada tiga unsur dalam agama sesuai definisi Durkheim yaitu pertama, kepercayaan bahwa hal-hal tertentu bersifat sakral ( dilarang, terpisah dari yang duniawi). Kedua, Pratik atau ritual yang berpusat pada hal-hal yang bersifat sakral. Ketiga, suatu komunitas moral yang muncul dari kepercayaandan Pratik suatu kelompok.

Sementara itu, di era new media atau media baru, yang lahir dari perkembangan internet, merupakan media yang menawarkan interaktifitas dan pola komunikasi yang dinamis. Media baru berbasis internet, memungkinkan penggunanya untuk menggunakan ruang seluas-luasnya di new media, memperluas jaringan seluas-luasnya, dan menunjukkan identitas yang lain dengan yang dimiliki pengguna tersebut di dunia nyata ${ }^{15}$.

Media baru muncul di akhir abad ke-20 dengan kekuatan komputerisasi dan teknologi komunikasi, peralatan konsumen berbasis komputer dan yang paling penting, internet. Media baru memungkinkan akses tanpa batas, kapan saja, dimana saja dan dengan perangkat digital apapun. Perangkat yang mendukung untuk menyediakan fasilitas umpan balik secara langsung, berbagai partisipasi kreatif, dan terbentuknya berbagai komunitas yang mengiringi konten-konten media ${ }^{16}$.

New media memiliki karakteristik yang berbeda dengan media konvensional (cetak atau elektronik), yakni: (1) Multimedia, dapat memuat atau menyajikan berita atau informasi dalam bentuk teks, audio, video, grafis, dan gambar secara bersamaan (2) Aktualisasi, berisi informasi aktual karena kemudahan dan kecepatan penyajian (3) Cepat, begitu diposting atau di unggah, langsung bias diakses semua orang (4) Upd ate, pembaruan (updating)

\footnotetext{
15 Terry Flew. New Media: An Introduction. New York: Oxford University Press, 2002 
informasi dapat dilakukan dengan cepat baik dari sisi konten maupun redaksional, misalnya kesalahan ketik atau ejaan (5) Kapasitas luas, halaman web bias menampung naskah sangat panjang (6) Fleksibilitas, pemuatan dan editing naskah bisa kapan saja dan dimana saja, juga jadwal terbit (update) bias dilakukan setiap saat (7) Luas, menjangkau seluruh dunia yang memiliki akses Internet (8) Interaktif, dengan adanya fasilitas kolom komentar dan chat room. (9) Terdokumentasi, informasi tersimpan di "bank data” dan dapat ditemukan ketika diperlukan dan (10) Hyperlinked, terhubung dengan sumber lain (links) yang terkait dengan informasi tersaji.

\section{PENUTUP}

Belakangan, media sosial menjadi alat berkomunikasi dan penyebaran informasi tentang Islam ekstrim, radikal, dan konten bermuatan terorisme. Media sosial adalah bentuk turunan dari media baru. Media sosial yang bertolak dari basis teknologi internet, dengan berbagai platform yang populer seperti website, Facebook, Twitter, Instagram, dan YouTube, telah banyak mengubah dunia. Memutarbalikkan banyak pemikiran dan teori sosial yang sebelumnya sudah ada. Media sosial semakin membuka kesempatan tiap individu yang terlibat di dalamnya, untuk bebas mengeluarkan pendapatnya. Oleh karena para pemilik paham-paham ekstrim Islam memiliki kebebasan pendapat di media sosial, sudah selayaknya pula komunitas Islam seperti NU dan Muhammadiyah menghadapinya secara optimal. Dengan harapan, masyarakat tidak ada yang terjebak dalam paham-paham tersebut.

NU adalah komunitas atau organisasi Islam yang dibentuk pada 16 Rajab 1344 H (31 Januari 1926). Organisasi ini dipimpin oleh KH. Hasyim Asy'ari sebagi Rais Akbar. Untuk menegaskan prisip dasar orgasnisai ini, maka KH. Hasyim Asy'ari merumuskan Kitab Qanun Asasi (prinsip dasar), kemudian juga merumuskan kitab I'tiqad Ahlussunnah Wal Jamaah. Kedua kitab tersebut kemudian diejawantahkan dalam Khittah NU, yang dijadikan dasar dan rujukan 
warga NU dalam berpikir dan bertindak dalam bidang sosial, keagamaan dan politik ${ }^{17}$. Sedangkan Muhammadiyah Muhammadiyah didirikan di Kampung Kauman Yogyakarta, pada tanggal 8 Dzulhijjah 1330 H/18 Nopember 1912 oleh seorang yang bernama Muhammad Darwis, kemudian dikenal dengan $\mathrm{KH}$. Ahmad Dahlan. KH Ahmad Dahlan adalah pegawai kesultanan Kraton Yogyakarta sebagai seorang Khatib dan sebagai pedagang. Melihat keadaan ummat Islam pada waktu itu dalam keadaan jumud, beku dan penuh dengan amalan-amalan yang bersifat mistik, $\mathrm{KH}$ Ahmad Dahlan tergerak hatinya untuk mengajak mereka kembali kepada ajaran Islam yang sebenarnya berdasarkan Qur’an dan Hadist. Oleh karena itu, KH Ahmad Dahlan memberikan pengertian keagamaan dirumahnya ditengah kesibukannya sebagai Khatib dan para pedagang $^{18}$.

Kekuatan yang dimiliki media sosial selayaknya digunakan oleh komunitas Islam untuk membendung konten negative Islam ekstrim. Selama ini, NU dan Muhammadiyah sudah mengaktifkan akun media sosial masingmasing. Tapi tentu, masih terbuka ruang-ruang untuk mengoptimalisasikannya. Dengan demikian, dakwah maupun branding yang dilakukan dua pesantren tersebut terus bisa menjadi lebih baik.

Media sosial adalah sarana berkomunikasi dan penyebaran informasi di era modern atau di era media baru. Media sosial adalah jembatan antara masyarakat dan stakeholder dengan komunitas Islam, dalam hal ini NU dan Muhammadiyah. Oleh sebab itu, optimalisasi pemanfaatannya harus terus ditingkatkan.

\section{REFERENSI}

\footnotetext{
${ }^{17}$ https://nu.or.id/static/6/sejarah-nu

${ }^{18}$ http://www.muhammadiyah.or.id/id/content-50-det-sejarah.html
} 
Abidin, Djamaluddin. Komunikasi dan Bahasa Dakwah, Jakarta: Gema Insani Press, 1996

Basit, Abdul. "Dakwah Cerdas di Era Milenial”. Jurnal Komunikasi Islam. ISBN 2088-6314. Volume 03, Nomor 01, Juni 2013.

Darwis, M. (2016). Teologi Dakwah Dalam Kajian Paradigmatik. Dakwatuna: Jurnal Dakwah dan Komunikasi Islam, 2(1), 85-106.

Farid, A. (2019). Optimalisasi Media Sosial Pesantren untuk Membendung Konten Negatif di Dunia Maya. Dakwatuna: Jurnal Dakwah dan Komunikasi Islam, 5(1), 30-37.

Flew, Terry. New Media: An Introduction. New York: Oxford University Press, 2002

Gamble, M. \& Teri K. G. Communication Works. Boston: McGraw Hill Education, 2002

Ghofur, A. (2019). Dakwah Islam Di Era Milenial. Dakwatuna: Jurnal Dakwah dan Komunikasi Islam, 5(2), 136-149.

Giddens, Anthony. The Consequences of Modernity, Stanford University Press, California, 1990

Ilahi, Wahyu. Komunikasi dakwah, Bandung: Remaja Rosdakarya, 2010

Lincoln, Yvonna S \& Egon G. Guba. Naturalistic Inquiry. California: Sage, 1985. Lindlof, T.R, \& Taylor B.C. Qualitative Communication Research Methods, Edisi 2. California: Sage Publications, 2002.

Mala, F. (2017). “E-Dakwah”: Tinjauan Awal Kontestasi Islam, Dakwah, Dan Internet. Dakwatuna: Jurnal Dakwah dan Komunikasi Islam, 3(1), 12-26.

Mala, Faiqotul. (2020). Mengkaji Tradisi Nabi Sebagai Paradigma Dakwah Yang Ramah. Dakwatuna: Jurnal Dakwah dan Komunikasi Islam, 6(01), 104-127.

Rachman, R. F. (2017). Menelaah riuh budaya masyarakat di dunia maya. Jurnal Studi Komunikasi, 1(2), 206-222.

Rachman, R. F. (2018). Dakwah Intraktif Kultural Emha Ainun Nadjib. Jurnal Spektrum Komunikasi, 6(2), 1-9. 
Rachman, R. F. (2019). Optimalisasi Media Digital Berbasis Kemaslahatan Umat dalam Program Pahlawan Ekonomi Surabaya. IQTISHODUNA: Jurnal Ekonomi Islam, 8, 273-292.

Rachman, R. F. (2019). Optimalisasi Teknologi Komunikasi Informasi Command Center Bagi Efektifitas Tenaga Kesejahteraan Sosial Kecamatan. Dakwatuna: Jurnal Dakwah dan Komunikasi Islam, 5(2), 170-180.

Shadrina, E. (2015). E-Dakwah Nahdatul Ulama Dan Muhammadiyah:

Penggunaan Twitter Sebagai Media Dakwah Kontemporer (Master Thesis, Universitas Airlangga)

Suciska, Wulan. 2016. “Optimalisasi Penerapan E-Government Melalui Media Sosial Dalam Mewujudkan Good Governance", Prosiding: Akselersi Pembangunan Masyarakat Lokal Melalui Komunikasi Dan Teknologi Informasi Wakefield, Daisy., Sklair, Aphra.,\&Gibson, Andy. Philanthropy and Media Social. The Institute of Philanthropy, 2011. Tautan http://www.tpw.org/images/ files/ philanthropy_and_social_media.pdf diakses pada 20 Desember 2017 Yin, Robert K. Case Study Research: Design and Methods. London: Sage Publication, 2003.

Zamzamy, A. (2019). Menyoal Radikalisme di Media Digital. Dakwatuna: Jurnal Dakwah dan Komunikasi Islam, 5(1), 13-29. 